\title{
プラズマ溶射 $\mathrm{Ni}-50 \mathrm{Cr}$ 皮膜の組織, 物性および溶射条件の相関性*
}

\author{
園家 㤵呞**, 李 長久***, 李 福海***

\begin{abstract}
Relationships between Microstructure, Mechanical Properties of Plasma-sprayed $\mathrm{Ni}-50 \mathrm{Cr}$ Coatings and Spray Parameters*
\end{abstract}

by Keiji SONOYA**, Chang-Jiu LI*** and Fu-Hai LI***

\begin{abstract}
The $\mathrm{Ni}-50 \mathrm{Cr}$ coatings are prepared under different plasma spray conditions which are arranged according to the orthogonal experimental design method using three typical parameters of plasma arc current, Ar flow and spray distance in order to obtain the quantitative regression correlations between spray parameter and coating mechanical properties, and examine the relationship between the mechanical properties and microstructure features. The mechanical properties of sprayed $\mathrm{Ni}-\mathrm{Cr}$ coatings are characterized by hardness, abrasive wear weight loss and erosion rates. The microstructure of the coatings is examined by optical and electron scanning microscopes. The porosity in the coating is quantitatively estimated from by the increase in $\mathrm{Cr}$ content of the coating after the impregnation of $\mathrm{Cr}_{2} \mathrm{O}_{3}$ into pores of the coating. The effects of spray parameters on the mechanical properties of the coating are discussed according to regression formulas systematically.

The results evidently show that three typical parameters have significant inter-effects on the microstructure and properties of the Ni-Cr coatings. There are evident correlations among the hardness and abrasive wear resistance, and porosity for plasma sprayed $\mathrm{Ni}-\mathrm{Cr}$ coatings. With the decrease in the porosity of the coating, the hardness and abrasive wear resistance of the $\mathrm{Ni}$-Cr coating are increased. On the other hand, there are no correlations between erosion resistance and hardness, and porosity as well. It has been found that the abrasive wear occurs mainly by micro-cutting of abrasives while the erosion occurs mainly by the successive separation of flattened particles exposed to the surface which are subjected to the direct impact of erosive particles. Therefore, the abrasive wear resistance is primarily dependent on the density and hardness of the coating, while the erosion wear is mainly dependent on the condition of the cohesion between flattened particles. The results also revealed that the deposition of partially melted particles into the coating deteriorates the erosion resistance of the coating, especially at low impact angle.
\end{abstract}

Key Words: Thermal spraying, Plasma spraying, Ni-50Cr, Coating, Microstructure, Orthogonal regression, Hardness, Abrasive Wear, Erosive Wear

\section{1. 緒言}

ボイラチューブのような高温環境下にある部材は通常バ ナジウムやサルファなどの厳しい腐食環境にさらされ る ${ }^{11}$.また, 現在多く使用されているゴミ焼却ボイラの場合 では，燃料の種類や燃焼条件によっても腐食条件が変わる ため2) 腐食現象も一段と複雑である。

一方, 溶射皮膜は, ボイラチューブなどの部材の摩耗と 腐食の防止のために使用されている. 高温腐食に対しては, クロム含有量が $20 \%$ を超える $\mathrm{NiCr}$ 合金が優れた耐食性を 示寸ことが多くの適用事例から明らかであり，その溶射 $\mathrm{NiCr}$ 皮膜は耐食皮膜として非常に優れている3,4. 一方, こ のような溶射皮膜を有効に利用するためには, 皮膜が十分 な密着性と耐摩耗性などの機械的特性を有することも重要

\footnotetext{
*原稿受付 平成12年 1 月11日 平成11年度秋季全国大会で発表

**正員石川島播磨重工侏 Member, Ishikawajima. Harima Heavy Industries Co., Ltd.

*** 西安交通大学 Xi'an Jiaotong University
}

である.このため，皮膜の耐食性と共に，機械的特性も最 適化することが必要である， Ni-Cr 溶射皮膜の機械的特性 を向上するには，溶射後の熱処理 ${ }^{5}$ や減圧溶射における溶 射中の温度制御6)の立場から検討されており，1273 K 以上 の後熱処理により皮膜の熱衝撃性が大幅に向上され, 減圧 溶射中に表面温度を $933 \mathrm{~K}$ 以上に保持すると皮膜の引張強 度が大きく増加されることが羿められた．皮膜の先際の適 用を考慮すると，大気溶射では溶射条件の立場から，皮膜 の機械特性を最適化することが重要である.しかしながら， $\mathrm{Ni}-\mathrm{Cr}$ 溶射皮膜の適用に関して，その皮膜の機械的特性を 系統的に論じる報告は少ないのが現状である.

$$
\text { そこで, 本研究ではプラズマアーク電流, プラズマガス }
$$
流量と溶射距離をパラメータとして取り上げ，直交回帰実 験計画法を用い，プラズマ溶射 $\mathrm{Ni}-\mathrm{Cr}$ 皮膜の組織に及ぼす 溶射条件の影響を検討すると共に，皮膜の機械的特性とパ ラメータとの関係を定量的に求め, 皮膜の組織と特性と溶 射条件との関係を検討した。 


\section{2. 実 験 方 法}

\section{1 供試材料}

供試材料として母材には 1 mass\% $\%$ r -0.5 mass\%Mo 鋼 （JISG3462-STBA22）を主に用いた。溶射材料には市販の

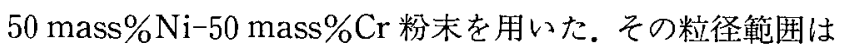
45-96 $\mu \mathrm{m}$ であった.

\section{2 試験片作製方法}

プラズマ溶射装置として $80 \mathrm{~kW}$ 級のプラズマ溶射シス テム（Jiujiang-GP-80）を用いた。 プラズマ作動がスとし て Arを用いた。二次ガスとして水素がスを用いた.プラズ マ作動中に扔いて Ar ガスと水素がスの圧力をそれぞれ $0.7 \mathrm{MPa}$ と0.4 MPa とした。試験中, ほかの条件を一定と し，プラズマアーク電流，プラズマ作動ガス流量と溶射距 離を三つのパラメータとして 5 レベルの值を選び, 直交回 㷌実験計画法に基づき変化させ, 皮膜を作製した. Table 1 に各因子のレベルとそのレベルに対応する各パラメータの

Table 1 The levels of spray parameters and the values corresponding individual levels.

\begin{tabular}{cccc}
\hline \multirow{2}{*}{ Levels } & \multicolumn{3}{c}{ Spray parameters } \\
\cline { 2 - 4 } & $\begin{array}{c}\text { Arc current } \\
(\mathrm{A})\end{array}$ & $\begin{array}{c}\text { Ar flow } \\
(\text { l/min) }\end{array}$ & $\begin{array}{c}\text { S.D* } \\
(\mathrm{mm})\end{array}$ \\
\hline$+\mathrm{r}$ & 601.2 & 57.2 & 164. \\
+1 & 583 & 55 & 160 \\
0 & 500 & 45 & 140 \\
-1 & 417 & 35 & 120 \\
$-\mathrm{r}$ & 398.8 & 32.8 & 115.7 \\
\hline
\end{tabular}

*: S.D-Spray distance

Table 2 The combinations of spray parameter levels by the orthogonal regression experimental design.

\begin{tabular}{cccc}
\hline Exp. runs & Arc current & Ar flow & S.D. \\
\hline 1 & 1 & 1 & 1 \\
2 & 1 & 1 & -1 \\
3 & 1 & -1 & 1 \\
4 & 1 & -1 & -1 \\
5 & -1 & 1 & 1 \\
6 & -1 & 1 & -1 \\
7 & -1 & -1 & 1 \\
8 & -1 & -1 & -1 \\
9 & $+\mathrm{r}$ & 0 & 0 \\
10 & $-\mathrm{r}$ & 0 & 0 \\
11 & 0 & $+\mathrm{r}$ & 0 \\
12 & 0 & $-\mathrm{r}$ & 0 \\
13 & 0 & 0 & $+\mathrm{r}$ \\
14 & 0 & 0 & $-\mathrm{r}$ \\
15 & 0 & 0 & 0 \\
\hline
\end{tabular}

実際の值を示す.実験条件の組み合わせは Table 2 に示す。 そこでは $\mathrm{X}_{1}, \mathrm{X}_{2}$ と $\mathrm{X}_{3}$ を用い，それぞれプラズマアーク電 流，プラズマ作動ガス（Ar）流量と溶射距離を表す。溶射 中においてプラズマアーク電流と $\mathrm{Ar}$ 流量が変化する際 に, 水素流量を調整してプラズマアーク電圧を $60 \mathrm{~V}$ と一定 た。そのほかの溶射条件は実験中において一定とした。

そして，以上のパラメータの組み合わせにより溶射した 試験片に对して，その組織を観察すると共に，その特性を 試験により求めた。次に，三つのパラメータを変数とする 特性值の二次回㷌式を求め, 皮膜の特性に及ぼす溶射条件 の影響を検討した。

なお，皮膜を作製する前に，母材表面に対して，24メッ シュのアルミナグリトを用い, 0.5 MPa の圧縮空気でサン ドブラスト処理を施した。

\section{3 試験方法}

皮膜の機械的特性として, 皮膜の断面硬さ，耐アブレシ ブ摩耗特性, 耐エロージョン摩耗性を検討した。硬さは荷 重1.98 Nでのマイクロビッカース硬さ（Hv）で評価した。 皮膜の断面において10点の硬さを測定し，その平均を皮膜 硬さとした。

アブレシブ摩耗は ASTM-G65-917)に準じる乾式ゴム 輪摩耗試験法によって皮膜の摩耗減量で評価した。測定条 件は，荷重が $13 \mathrm{~N}$ で，回転速度が50 RPM で，摩耗時間を 15分とした。研磨剤には120メッシュのアルミナを用いた。

エロージョン摩耗特性の評価は噴射摩耗試験機を用いて 行った。噴射ノズルは直径が $3.6 \mathrm{~mm}$ で，長さが $22 \mathrm{~mm}$ の ものを用いた。噴射材の加速用の圧縮空気圧は $0.35 \mathrm{MPa}$ で, その流量は $141 \mathrm{l} / \mathrm{min}$ とた。ノズルから試験片中心ま での距離を $100 \mathrm{~mm}$ とし, 試験片のサイズは $65 \times 45 \times 5 \mathrm{~mm}$ とした。噴射材は60メッシュのアルミナを用いた。試験は それぞれ $30^{\circ} と 90^{\circ}$ の噴射角度下で行った。

皮膜の断面組織は光学顕微鏡と走査型電子顕微鏡で観察 した．皮膜の積層構造を明らかにするために，皮膜組織の 観察を行う前に, 飽和クロム酸溶液を用い, 皮膜に対して 酸化クロム充填を行った，充填試験に当たって，まず，試 験片をク口ム酸溶液中に $1800 \mathrm{sec}$ 含浸し，その後乾燥して から, $773 \mathrm{~K} \times 1800 \mathrm{sec}$ 熱処理して， $\mathrm{Cr}_{2} \mathrm{O}_{3}$ に分解させ，皮 膜の気孔中に穔層させる.10回繰り返して立填することに より，皮膜中の気孔はほとんど充填されることになる8,99. そして，充墳による皮膜中のク口ムの増加量によって皮膜 の気孔率を求めた ${ }^{10)}$.

\section{3. 実験結果および考察}

\section{1 プラズマ溶射 $\mathrm{Ni}-50 \mathrm{Cr}$ 皮膜の組織}

Fig. 1 (a), (b)と(c)はほかの条件が一定で, プラズマ作動が ス中の $\mathrm{Ar}$ 流量がそれぞれ32.81/min，451/min と57.21/ 


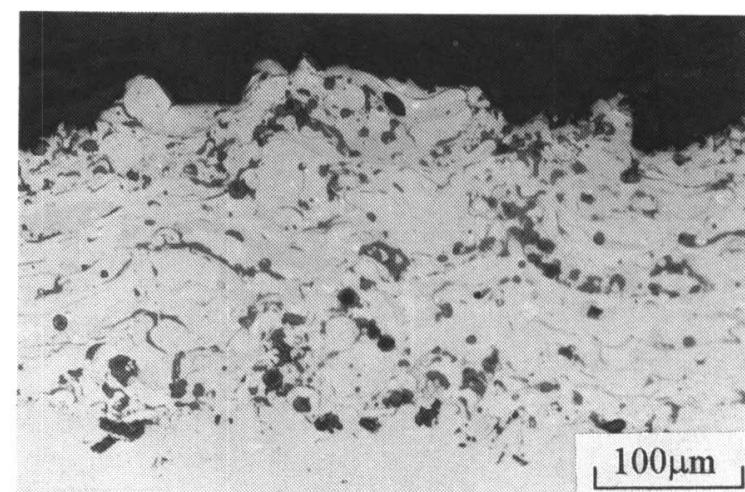

(a)

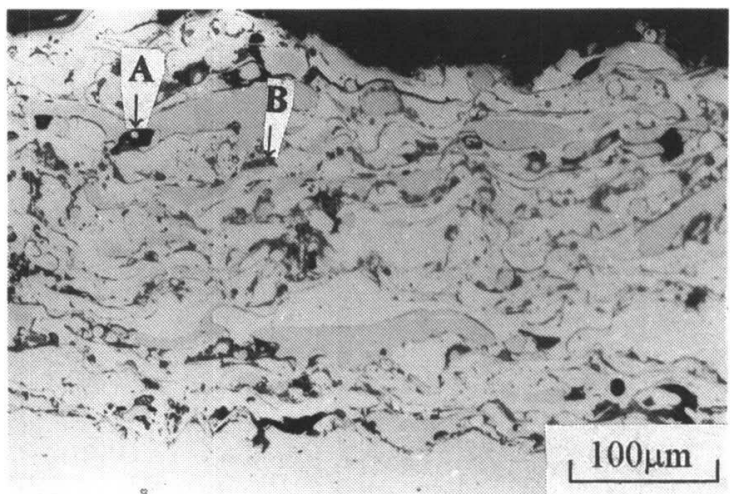

(b)

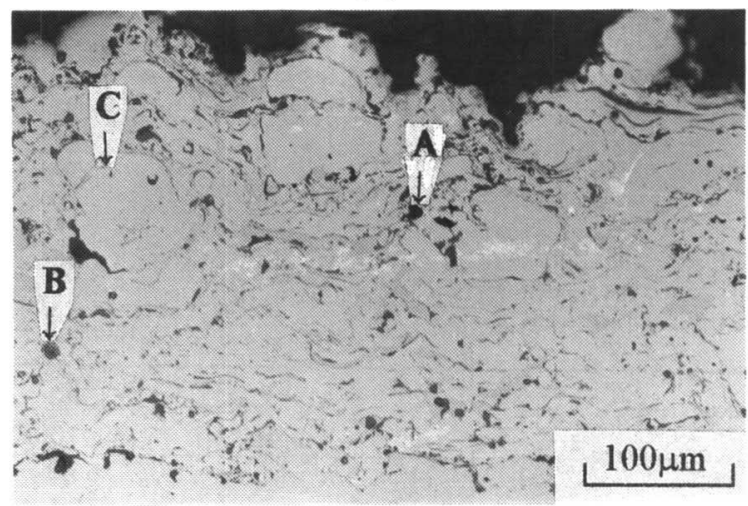

(c)

Fig. 1 Effect of Ar flows on the microstructure of plasmasprayed $\mathrm{Ni}-50 \mathrm{Cr}$ coatings under arc current $500 \mathrm{~A}$ and spray distance $140 \mathrm{~mm}$ : (a) $32.8 \mathrm{l} / \mathrm{min}$; (b) $45 \mathrm{l} /$ min ; (c) $57.2 \mathrm{l} / \mathrm{min}$. (A-porosity ; B-Oxide ; C-unmelted particle)

$\min ($ 対応する水素流量はそれぞれ $17.8,13$ と $8.41 / \mathrm{min} て ゙$ あった）下において作製された皮膜の断面組織を示す。図 から, 皮膜は積層構造を示し, 皮膜中に未溶融粒子のほか, 気孔，そして，酸化物の存在も認吼れ. Ar 流量の増加 に従って，未溶融粒子が皮膜中に多く積層されることが分 かる．これはプラズマアーク電流と電圧（すなわち出力） が一定の場合では, $\mathrm{Ar}$ 流量の増加は $\mathrm{H}_{2}$ 流量の減少を伴 う. 水素がス流量の減少は粒子に対するプラズマの加熱効 果の低減をもたらすためと考之られる。それから，四から， $\mathrm{Ar}$ 流量が少ない場合, 皮膜中に多くの酸化物の存在が認め

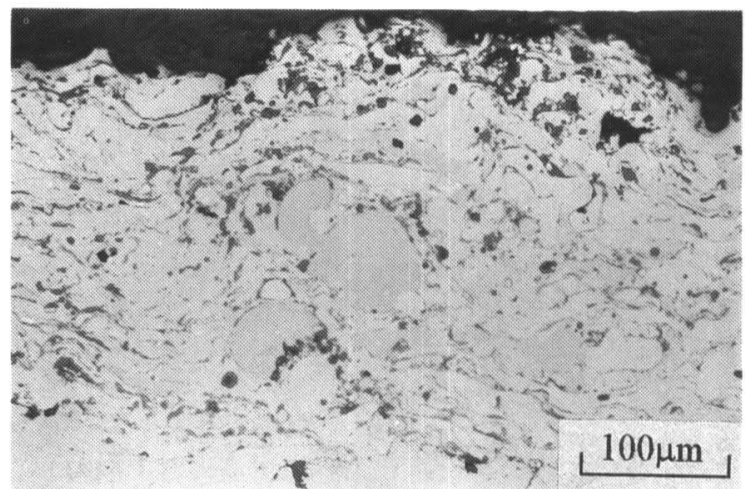

(a)

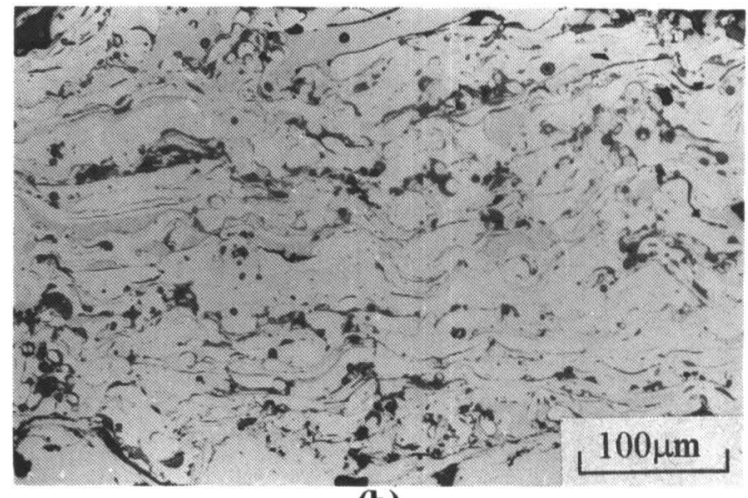

(b)

Fig. 2 Typical microstructures of plasma-sprayed $\mathrm{Ni}$ $-50 \mathrm{Cr}$ at an arc current $500 \mathrm{~A}$ and Ar flow $45 \mathrm{l} / \mathrm{min}$ coatings and under different spray distances: (a) $115.7 \mathrm{~mm}$; (b) 164.3 .

られるが, $\mathrm{Ar}$ 流量が大きい場合, 皮膜中に多くの未溶融粒 子の存在にもかかわらず, 皮膜組織は比較的緻密で, 酸化 物の存在量も割りに少ないのが認められる.

Fig. 2 に皮膜の断面組織に及ぼす溶射距離の影響を示 す. 溶射距離が $115.7 \mathrm{~mm}$ と短くなると, 皮膜中に未溶融粒 子の積層が多くなるのが認められる。これは距離が短いた め，粒子に対する加熱が不充分であると考えられる。

一般的に, 皮膜を積層する溶射粒子の溶融状態はプラズ マ出力の増加により改善される，その溶融状態はプラズマ 出力が小さい場合, ほかのパラメー夕に容易に左右される が，プラズマ出力が大きい場合，ほかのパラメータの影響 を受けにくいと考之られる. Fig. 3 には Ar 流量が55 1/min と大きく, そして, 距離が $120 \mathrm{~mm}$ と短く,さらにプラズマ 電流が $400 \mathrm{~A}$ と小さい条件で作製した皮膜の断面組織を示 す。皮膜中に未溶融粒子のほかに, 多くの気孔，そして多 くの酸化物の存在が認められる。この結果から, 粒子に対 する加熱の効果に対して, 溶射距離とプラズマ作動がスを 含む溶射条件の影響には相乗効果が存在するのが明らかに 分かる. 従って, 溶射粒子の溶融状態を良くし, 緻密な皮 膜を作製するためには，一定の出力のプラズマジェットを 用い，適切な距離で溶射を行うことが必要である。なお， Fig. 3 (b)に示される酸化ク口ム立媜を行った皮膜断面組織 


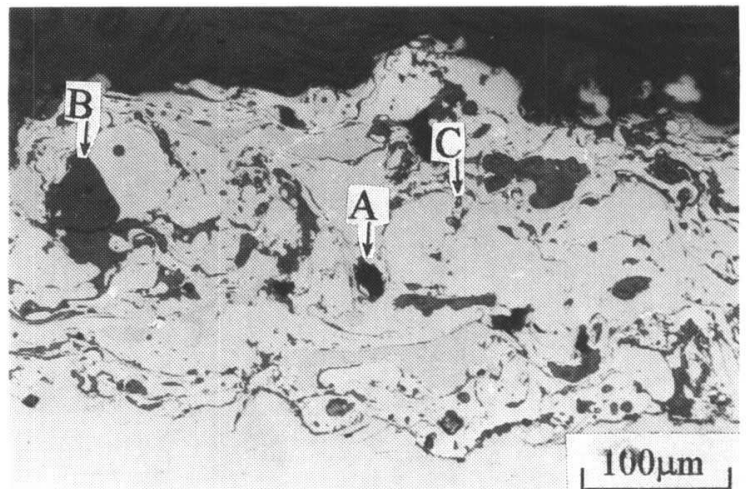

(a)

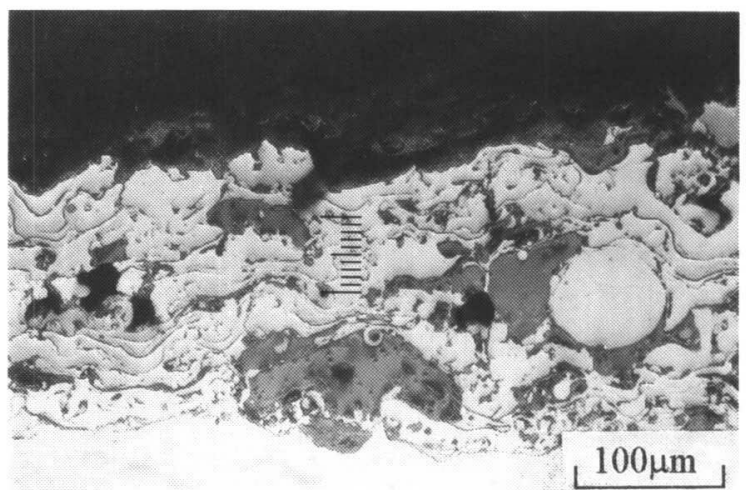

(b)

Fig. 3 The typical microstructure of the $\mathrm{Ni}-50 \mathrm{Cr}$ coating deposited with partially melted particles under an arc current $400 \mathrm{~A}$, Ar flow $55 \mathrm{l} / \mathrm{min}$ and spray dis tance $120 \mathrm{~mm}$ : (a) as-sprayed ; (b) impregnated with $\mathrm{Cr}_{2} \mathrm{O}_{3}$. (A : pore; $\mathrm{B}$ : oxide; $\mathrm{C}$ : partially melted particle)

から，多くの粒子間に酸化物の存在が認められる.

また, Fig. 4 (b)に示す皮膜断面組織からも, 距離が短い場 合では，皮膜中に灰色となる細かい酸化物が積層粒界に多 く存在することが認められる。溶射中に打いて，金属粒子 は飛行中に加熱されながら表面から順次に酸化が進行し， 溶射距離が増加すると共に酸化物の量が多くなると考えら れる。しかし，本研究で作成された皮膜の断面組織から距 離が $120 \mathrm{~mm}$ と短い場合では，皮膜中の粒子間に多く酸化 物の存在が認められる。この現象は粒子の溶融状態が不立 分なため，積層された皮膜表面に衝突する際に，粒子は未 溶融の中心部と溶融シェ儿部からなる液固二相となり，溶 融部分が表面に覆われた酸化物と一緒に優先的に積層され る11) ためと考之られる.

以上の結果より，皮膜の組織は，溶射条件に依存する溶 射粒子の溶融状態に大きく影響されると考えられる。プラ ズマ出力が大きく，プラズマ作動ガス中の $\mathrm{Ar}$ ガスの流量 が適切で，粒子の加熱時間が若干長い距離では，溶射粒子 の溶融状態がよく, Fig. 4 (a)に示すような緻密な皮膜が形 成される。

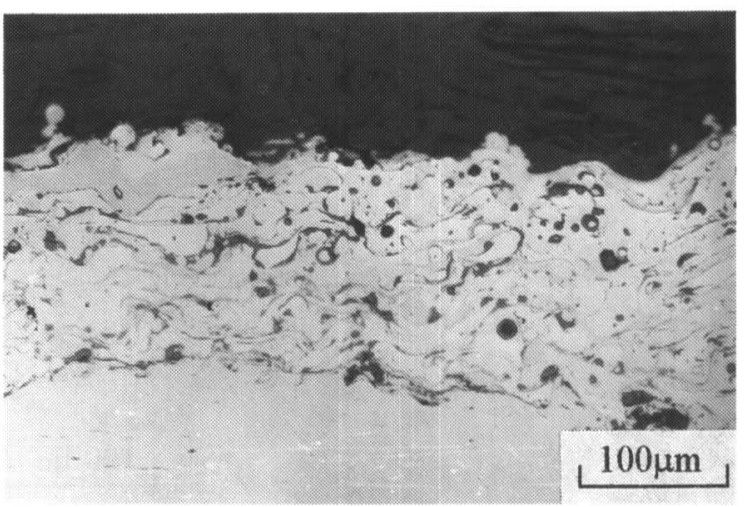

(a)

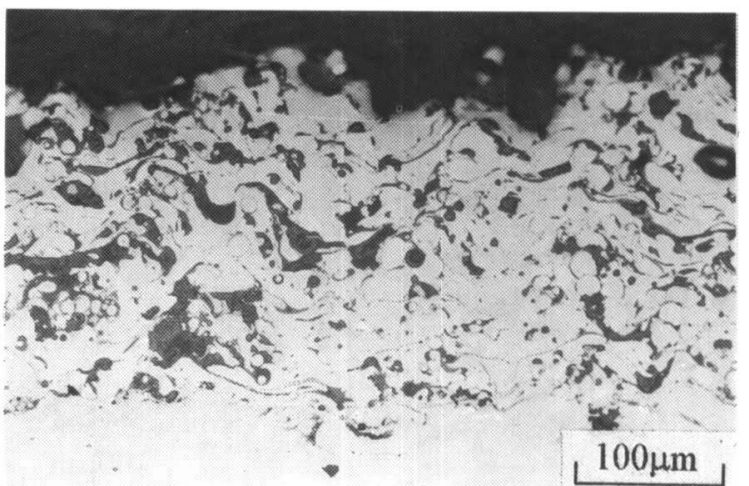

(b)

Fig. 4 The effect of spray parameter combinations on the microstructure of the $\mathrm{Ni}-50 \mathrm{Cr}$ coatings: (a) under experimental run No. 1 ; (b) under experimental run No. 8 .

Table 3 Experimental results for the mechanical properties of $\mathrm{Ni}-50 \mathrm{Cr}$ coatings plasma-sprayed under different combinations of spray parameters.

\begin{tabular}{ccccc}
\hline Exp. runs & $\begin{array}{c}\mathrm{Y}_{\mathrm{h}} \\
\left(\mathrm{H}_{\mathrm{v} 0.2}\right)\end{array}$ & $\begin{array}{c}\mathrm{Y}_{\mathrm{aw}} \\
(\mathrm{mg})\end{array}$ & $\begin{array}{c}\mathrm{Y}_{\mathrm{el}} \\
(\mathrm{mg} / 100 \mathrm{~g})\end{array}$ & $\begin{array}{c}\mathrm{Y}_{\mathrm{ev}} \\
(\mathrm{mg} / 100 \mathrm{~g})\end{array}$ \\
\hline 1 & 364 & 34.3 & 62.7 & 64.0 \\
2 & 360 & 37.7 & 68.5 & 76.5 \\
3 & 427 & 35.3 & 66.2 & 66.7 \\
4 & 338 & 40.5 & 69.8 & 72.3 \\
5 & 339 & 35.4 & 62.6 & 69.4 \\
6 & 229 & 37.5 & 66.2 & 60.8 \\
7 & 273 & 39.3 & 61.2 & 65.6 \\
8 & 294 & 40.7 & 67.0 & 69.6 \\
9 & 351 & 36.7 & 66.5 & 71.6 \\
10 & 401 & 35.2 & 63.5 & 66.2 \\
11 & 354 & 35.4 & 68.8 & 69.9 \\
12 & 351 & 37.8 & 63.5 & 66.5 \\
13 & 373 & 34.0 & 63.1 & 66.9 \\
14 & 328 & 37.6 & 73.3 & 75.3 \\
15 & 338 & 38.0 & 69.4 & 73.7 \\
\hline
\end{tabular}

\section{2 皮膜の機械的特性}

Table 3 に, Table 2 に示した15組の条件で作成した皮膜 の硬さ，アブレシブ摩耗量，30および90度の噴射角度にお けるエロージョン摩耗速度の結果を示寸。これらの結果か 
ら，明らかに皮膜の機械的特性は溶射条件に大きく影響さ れることが分かる.

\section{2 .1 皮膜硬さ}

皮膜の硬さは, Table 3 に示した結果より, 平均で $230 \mathrm{Hv}$ から $427 \mathrm{Hv}$ の範囲まで変化するのが分かる.三つの溶射条 件を変数とし，测定結果から求めた皮膜硬さの二次回帰式 は次のとおりである。

$$
\begin{aligned}
Y_{\mathrm{h}}= & -640-0.0465 \mathrm{X}_{1}+15.7 \mathrm{X}_{2}+6.67 \mathrm{X}_{3} \\
& +0.0027 \mathrm{X}_{1} \mathrm{X}_{3}-0.178 \mathrm{X}_{2}^{2}-0.0242 \mathrm{X}_{3}^{2}
\end{aligned}
$$

但し， $\mathrm{Y}_{\mathrm{n}}$ は皮膜硬さ $(\mathrm{Hv})$ で， $\mathrm{X}_{1}$ はプラズマアーク電 流 (A) で, $\mathrm{X}_{2}$ は $\mathrm{Ar}$ ガス流量 $(\mathrm{l} / \mathrm{min})$ で， $\mathrm{X}_{3}$ は溶射距 離 $(\mathrm{mm})$ である。この二次回帰式の $\mathrm{F}$ 検定の結果, $\mathrm{F}=$ $1.67>\mathrm{F}_{\alpha=0.25}(6,8)=1.65$. 従って, 上記の二次回帰式は $75 \%$ 以上の信頼性を持つ.

Fig. 5 にはプラズマアーク電流を $500 \mathrm{~A}$ と一定にした場 合に，上記の回帰式に基づいて求めた皮膜の硬さに及ぼす 溶射距離と Ar 流量の影響を示す。回帰式からも分かるよ うに溶射距離の増加と共に，皮膜の硬さは放物線的に増加 するが, 本研究の範囲内では, 距離が $160 \mathrm{~mm}$ から $170 \mathrm{~mm}$ までの範囲に最大となることが分かる。これは溶射粒子の 温度が距離の增加と共に均一化され, 溶融状態がよくなり, 皮膜が緻密化され，皮膜硬さが高くなるためと考えられる.

そして, 皮膜の硬さは, $\mathrm{Ar}$ 流量が約 $50 \mathrm{l} / \mathrm{min}$ まではその 増加と共に増加するが，それ以上流量が増加すると減少に 転じることが認められる。
一方，回帰式(1)の $\mathrm{X}_{1}$ に関する項から明らかなように, プ ラズマアーク電流の増加と共に，皮膜の硬さは増加するこ とが分かる。

\section{2 .2 アブレシブ摩耗特性}

Table 3 に示した皮膜のアブレシブ摩耗減量から，三つ の溶射条件をパラメータとして求めた二次回帰式は以下の 通りである。

$$
\begin{aligned}
\mathrm{Y}_{\mathrm{aw}}= & 75.8-0.018 \mathrm{X}_{1}-1.06 \mathrm{X}_{2}-0.0347 \mathrm{X}_{3} \\
& +0.000495 \mathrm{X}_{1} \mathrm{X}_{2}-0.000383 \mathrm{X}_{1} \mathrm{X}_{3} \\
& +0.0000457 \mathrm{X}_{1}^{2}+0.00757 \mathrm{X}_{2}^{2} \\
& +0.000539 \mathrm{X}_{3}
\end{aligned}
$$

但し， $\mathrm{Y}_{\mathrm{aw}}$ は皮膜の摩耗量 (mg) である。この回㷌式は $\mathrm{F}$ 検定の結果 $\left(\mathrm{F}=3.59>\mathrm{F}_{\alpha=0.1}(8,6)=2.89\right)$ から $90 \%$ 以 上の信頼性を有する. Table 4 には回帰式より計算された 摩耗量と，実験値との相対誤差を示す。多くの条件ではそ の相対鿁差は $3 \%$ 以内になっている.

Fig. 6 と Fig. 7 は, 各々異なった溶射距離において,アブ レシブ摩耗減量に及ぼすアーク電流と Ar ガス流量の影響 を示す。摩耗量はアーク電流の増加と共にある值までは減 少し, その後, 増加する傾向を示す.さらに，摩耗特性に 対して，溶射距離とアーク電流は相互作用があることが明 らかである，最少摩耗量となるア一ク電流は溶射距離に依 存し，120 mm では約 $450 \mathrm{~A}$ で, $160 \mathrm{~mm}$ では約600 A にな る. 更に, アーク電流が小さい場合，皮膜の摩耗量は大き く，溶射距離の影響は䫖著でない，しかし，電流が大きく

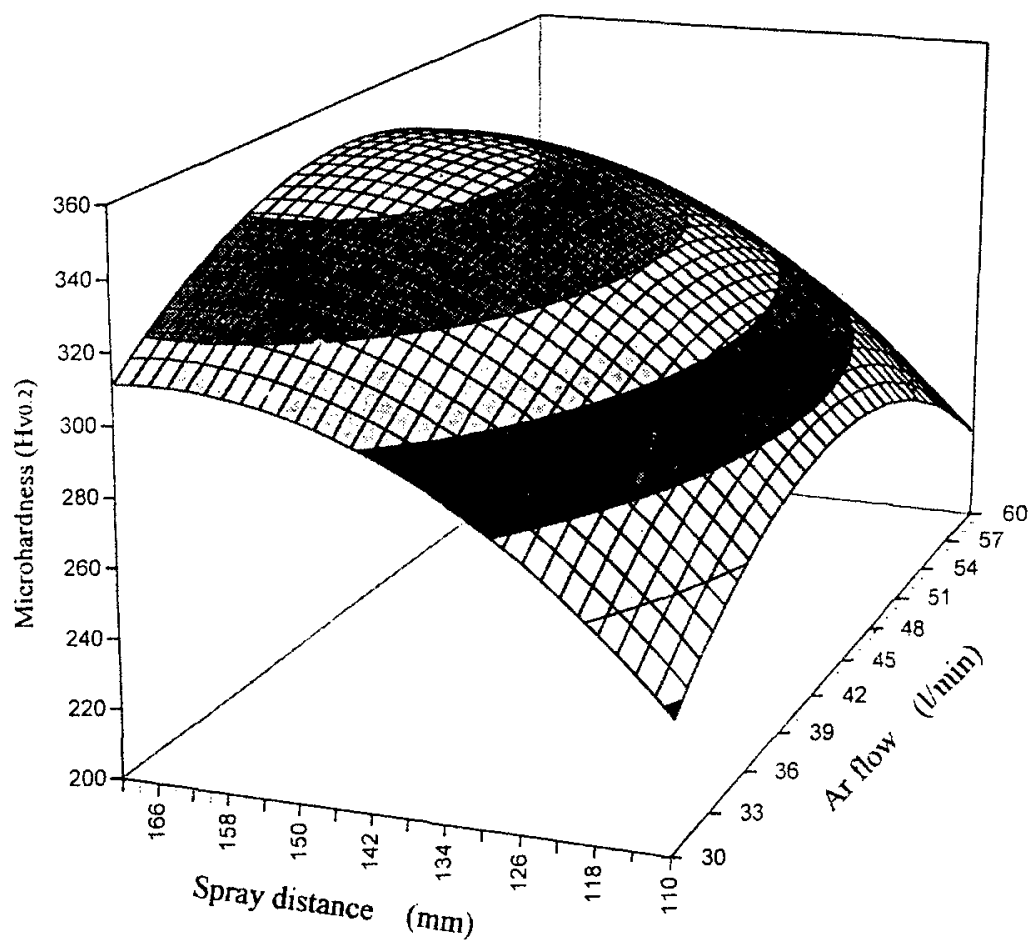

Fig. 5 Effects of spray distance and Ar flow on the microhardness of plasma-sprayed $\mathrm{Ni}-50 \mathrm{Cr}$ coatings (Arc current : $500 \mathrm{~A}$ ). 
Table 4 Comparison of observed abrasive wear weight loss with the calculated ones from the regression formula for the $\mathrm{Ni}-50 \mathrm{Cr}$ coatings.

\begin{tabular}{|c|c|c|c|c|c|c|c|c|c|c|c|c|c|c|c|}
\hline Exp.run & 1 & 2 & 3 & 4 & 5 & 6 & 7 & 8 & 9 & 10 & 11 & 12 & 13 & 14 & 15 \\
\hline Obs. & 34.3 & 37.7 & 35.3 & 40.5 & 35.4 & 37.5 & 39.3 & 40.7 & 36.7 & 35.2 & 35.4 & 37.8 & 34.0 & 37.6 & 38.0 \\
\hline Cal.* $^{*}$ & 34.1 & 38.4 & 35.8 & 40.1 & 35.1 & 36.9 & 38.5 & 40.2 & 36.2 & 36.9 & 35.7 & 38.7 & 34.6 & 38.2 & 36.1 \\
\hline Ers.** & 0.63 & 1.74 & 1.35 & 1.08 & 0.76 & 1.72 & 2.13 & 1.21 & 1.41 & 4.65 & 0.76 & 2.41 & 1.66 & 1.65 & 5.31 \\
\hline
\end{tabular}

Notes: ${ }^{*}$ calculated using regression formulas

** Ers is relative error between observed weight loss and calculated weight loss

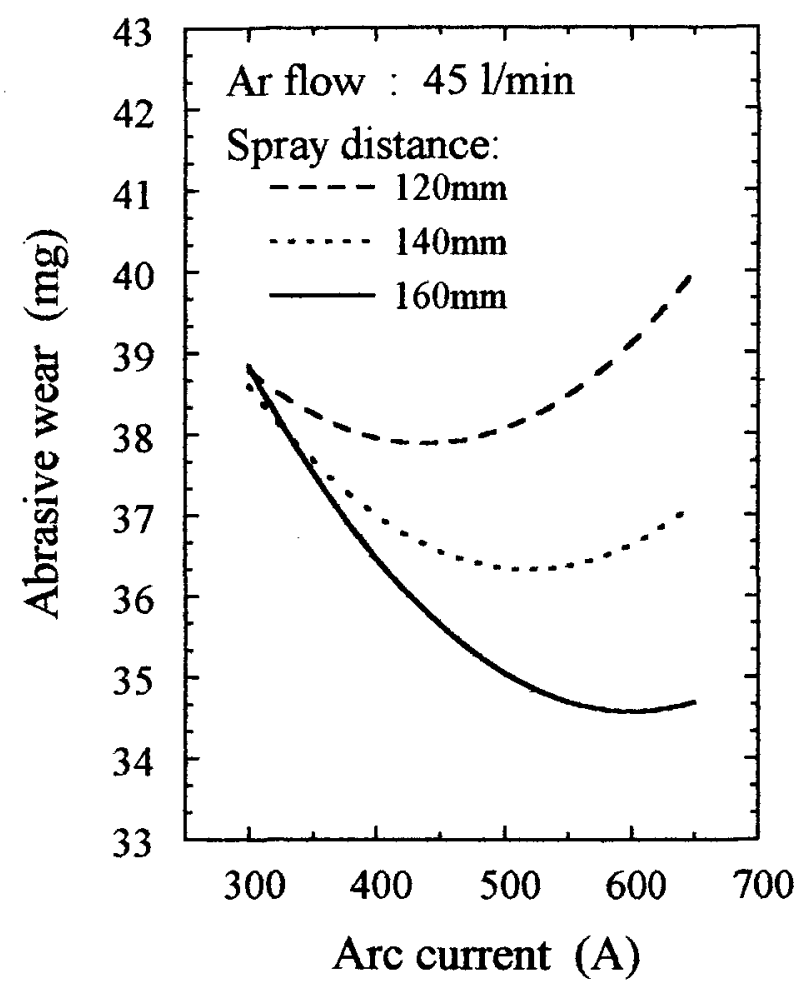

Fig. 6 Effect of arc current on the abrasive wear of plasma-sprayed $\mathrm{Ni}-50 \mathrm{Cr}$ coatings at different spray distances.

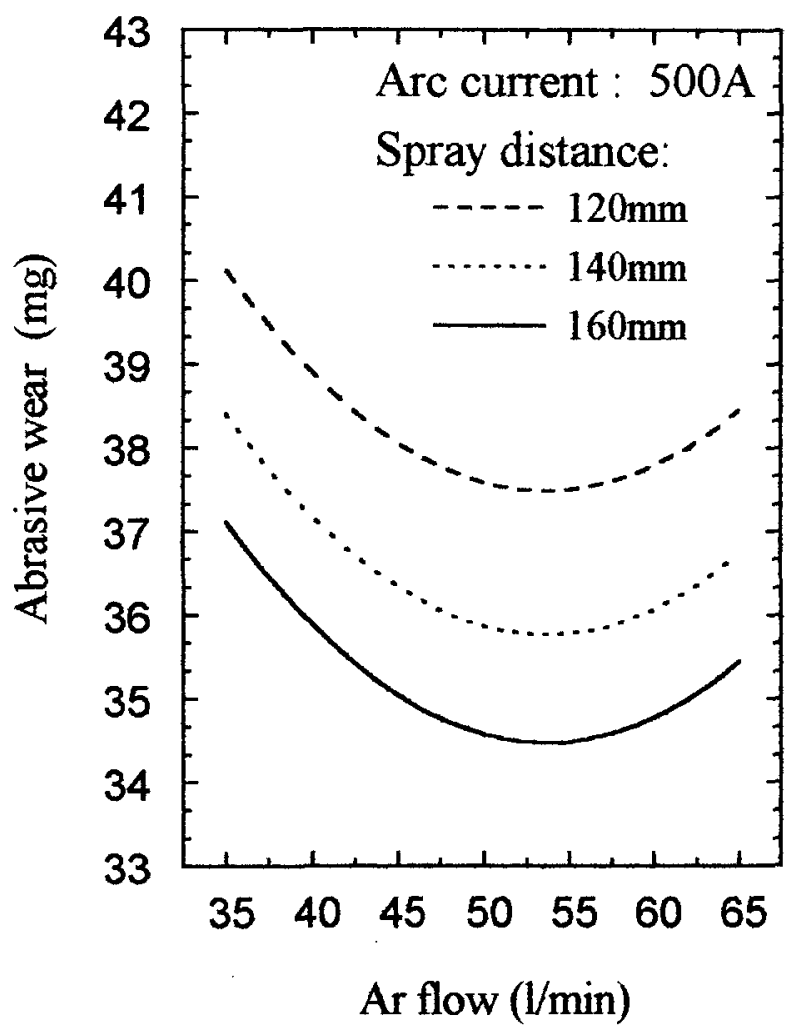

Fig. 7 Effect of Ar flow on the abrasive wear of plasmasprayed $\mathrm{Ni}-50 \mathrm{Cr}$ coatings at different spray distances.

量が約 $531 / \mathrm{min}$ まではその増加と共に減少するが，それ以 上に增加すると，逆に增加する傾向が認められる。この傾 向はFig. 5 に示された皮膜硬さと $\mathrm{Ar}$ 流量との関係に一致 する。

\section{2 .3 エロージョン摩耗特性}

皮膜の噴射摩耗減量と噴射摩耗材量との関係を検討した 結果，プラズマ溶射 $\mathrm{Ni}-50 \mathrm{Cr}$ 皮膜はほかの皮膜のエロー ジョン摩耗特性と同様に摩耗の初期では摩耗速度が大き く，摩耗材の量の増加と共に減少し，ある一定量以上にな 
ると, 摩耗速度は一定になることが認められた ${ }^{12,13)}$. 本研究 では，摩耗材を $60 \mathrm{~g}$ 以上に噴射すると，摩耗は定常摩耗状 態となり，摩耗速度は一定となった。Table 3 に示したエ ロージョン摩耗試験結果はこのような定常摩耗状態におけ る摩耗速度である． $30^{\circ}$ と $90^{\circ}$ に扔ける皮膜の摩耗速度を比 較すると, 噴射摩耗角度が大きく変わったにもかかわらず， 皮膜の摩耗速度はそれほど大きな差が認められなかった。

Table 3 に示した結果から, $30^{\circ}$ におけるエロージョン摩 耗速度に関寸る二次回帰式は次の上うに求められた。

$$
\begin{aligned}
\mathrm{Y}_{\mathrm{el}}= & -17.1+0.326 \mathrm{X}_{1}+1.44 \mathrm{X}_{2}-0.326 \mathrm{X}_{3} \\
& -0.000811 \mathrm{X}_{1} \mathrm{X}_{2}-0.000274 \mathrm{X}_{1}^{2}-0.0112 \mathrm{X}_{2}^{2} \\
& +0.000658 \mathrm{X}_{3}^{2}
\end{aligned}
$$

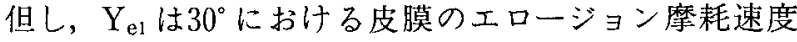
$(\mathrm{mg} / 100 \mathrm{~g})$ である.この回帰式の F検定の結果, F=3.45> $\mathrm{F}_{\alpha=0.1}(8,6)=2.89$.

$90^{\circ}$ におけるエロージョン摩耗速度に関して求められた 回帰式は次の通りである。

$$
\begin{aligned}
\mathrm{Y}_{\mathrm{ev}}= & -102+0.457 \mathrm{X}_{1}+0.938 \mathrm{X}_{2}+0.583 \mathrm{X}_{3} \\
& +0.000751 \mathrm{X}_{1} \mathrm{X}_{2}-0.0017 \mathrm{X}_{2} \mathrm{X}_{3}+0.00356 \mathrm{X}_{1}^{2} \\
& -0.00024 \mathrm{X}_{2}^{2}-0.0214 \mathrm{X}_{3}^{2}
\end{aligned}
$$

但し, $\mathrm{Y}_{\mathrm{ev}}$ は $90^{\circ}$ の噴射角度における皮膜のエロージョン 摩耗速度 $(\mathrm{mg} / 100 \mathrm{~g})$ である。この回帰式の $\mathrm{F}$ 検定の結果 は $\mathrm{F}=2.86>\mathrm{F}_{\alpha=0.1}(7,7)=2.78$ となった。

回帰式(3)と(4)から計算した摩耗速度を测定値と比較する と，ほとんどの条件下では，雨者の相対誤差は $5 \%$ 以内と

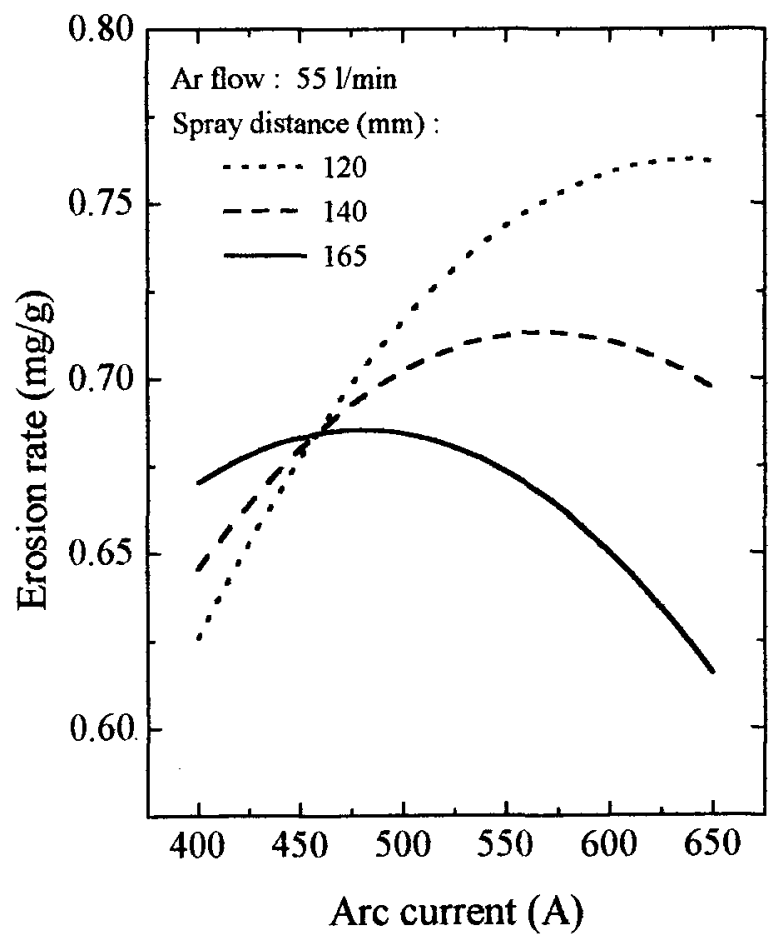

Fig. 8 Effect of arc current on the erosion rate of plasmasprayed $\mathrm{Ni}-50 \mathrm{Cr}$ coatings at different spray distances (Jet angle: $90^{\circ}$ ).
なるのが想められた. 従って, 雨式のF検定の結果からも 分かるように，これらの回帰式は皮膜のエロージョン摩耗

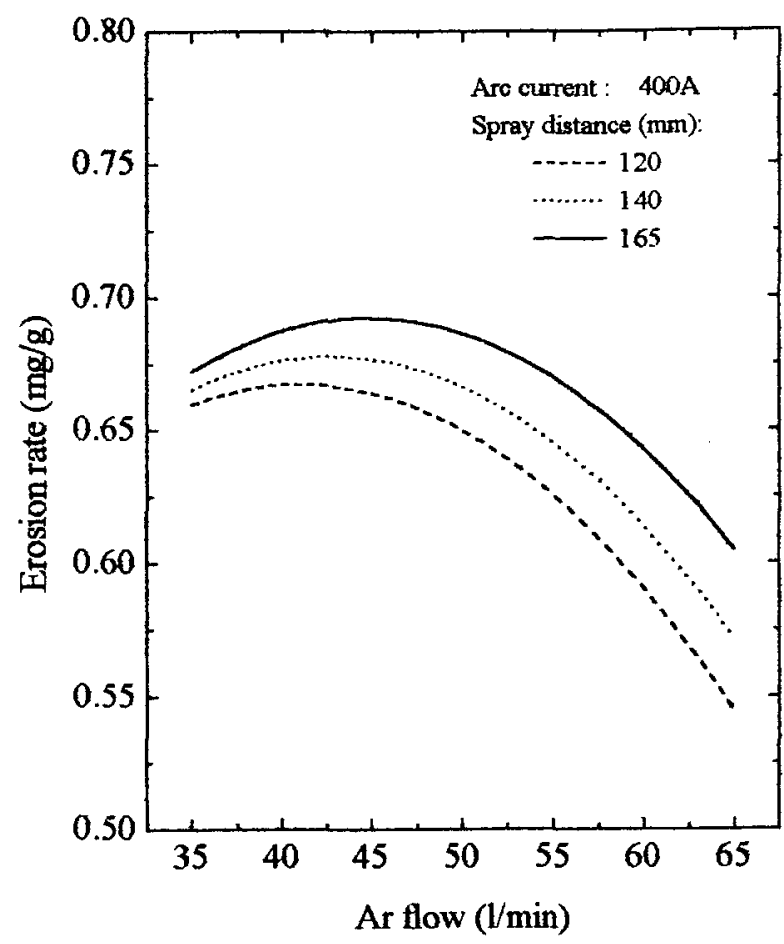

(a)

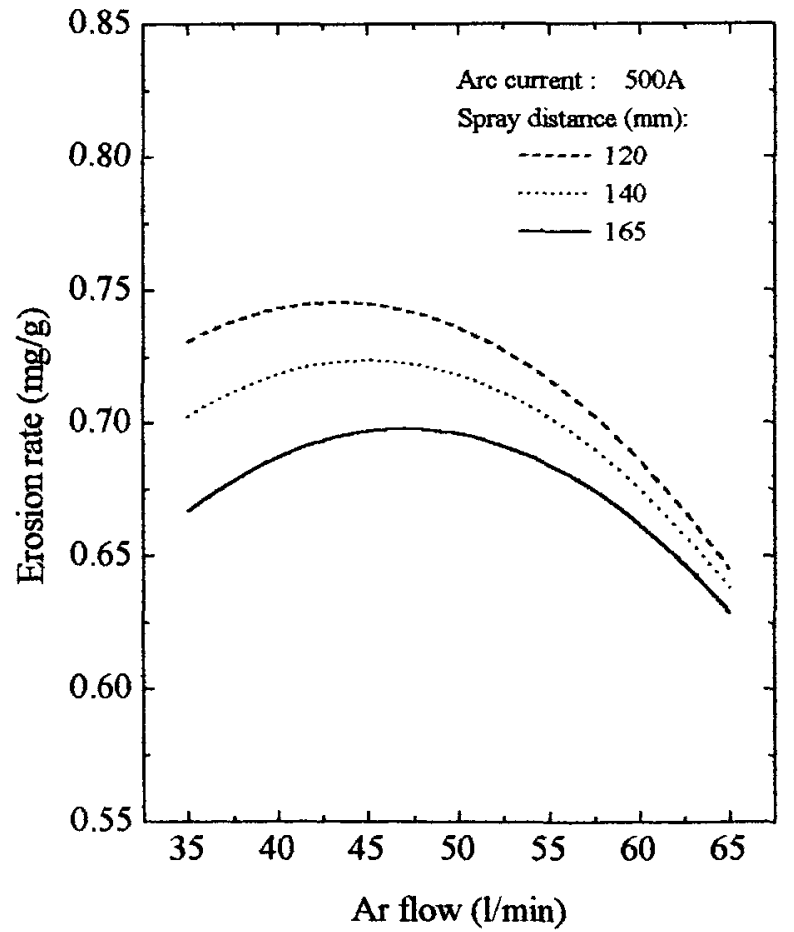

(b)

Fig. 9 Effect of Ar flow on the erosion rate of plasmasprayed $\mathrm{Ni}-50 \mathrm{Cr}$ coatings at different spray distances (Jet angle : $90^{\circ}$ ) : (a) Arc current : $400 \mathrm{~A}$; (b) Arc current: $500 \mathrm{~A}$. 
速度と溶射パラメータとの関係を良く表すものと考えられ る.

上記の回帰式(3)と(4)から, 溶射条件の影響を検討すると, 皮膜のエロージョンに対する影響は二つの噴射角度におい てほぼ同じ傾向を示すことが分かる.

回帰式(4)による $90^{\circ}$ での皮膜のエロージョン摩耗速度に 及ぼすプラズマアーク電流, $\mathrm{Ar}$ 流量の影響を異なった溶射 距離に対して，それぞれ Fig. 8 と Fig. 9 に示す. Fig. 8 か ら, 摩耗速度に及ぼすアーク電流の影響はアブレシブ摩耗 特性と同様, 溶射距離に大きく依存する。エロージョン摩 耗速度は, 溶射距離が短い場合電流の増加と共に増加する が, 溶射距離が長い場合電流の増加と共に減少する。一方, Fig. 9 (a)に示すように電流が400 A の場合, Ar 流量が50 1/ min 以下では, Ar 流量と溶射距離は摩耗速度にはあまり影 響を及ぼさないが，それ以上増加すると，その増加と共に

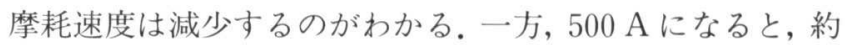
50 1/min 以下では, 溶射距離の影響は大きく現れ, Ar 流量 がそれより大きくなると，その影響は小さくなるのが認め られる。

\section{3 皮膜の特性と組織との関係}

\subsection{1 硬さとアブレシブ摩耗特性と組織との関係}

アブレシブ摩耗試験後の皮膜の表面形態と断面構造を観 察した結果, Fig. 10 に示すように, 表面では浅い削り痕が 見られるが, 断面は比較的平たい面を示していることが分 かった．従って， Ni-50Cr 溶射皮膜のアブレシブ摩耗はア ブレシブ粒子の切削作用によることが明らかである. Fig. 11 に示す皮膜の硬さに及ぼす気孔率の影響の結果から, 皮 膜の硬さは気孔率の減少, 即ち, 皮膜の緻密さの増加に従っ て向上するのが分かる. そして, Fig. 12 に示す皮膜のアブ レシブ摩耗量に及ぼす気孔率の影響より， Ni-50 Cr 溶射皮 膜は緻密になる程, 硬さが高くなって, 耐アブレシブ摩耗 性は向上することが明らかになった。

これらの結果から，回帰式(1)で示した溶射条件と皮膜の 硬さとの回帰式に基づいて皮膜の緻密さと溶射条件との関 係を考察すると, プラズマ出力の増加, そして溶射距離の 増加に従い, 皮膜の緻密さが増加することが推測される. この結果は3.1節に示した皮膜の断面組織の観察結果と一 致する、従って，皮膜の断面組織が緻密になる様な溶射条 件は，皮膜の硬さを増加して，その耐アブレシブ摩耗性の 向上にも結びつくと考えられる。一方，3.1節の結果から， 溶射距離が短く，プラズマ電流が小さい場合では，皮膜中 に多くの酸化物の存在が認められるが, これらは3.2.2節の 結果と合わせると, 皮膜中の酸化物は必ずしもその耐アブ レシブ摩耗性の向上に結びつかないと考えられる.

\section{3 .2 皮膜のエロージョン摩耗特性と組織の関係}

皮膜のエロージョン摩耗特性とその構造との関係をアル

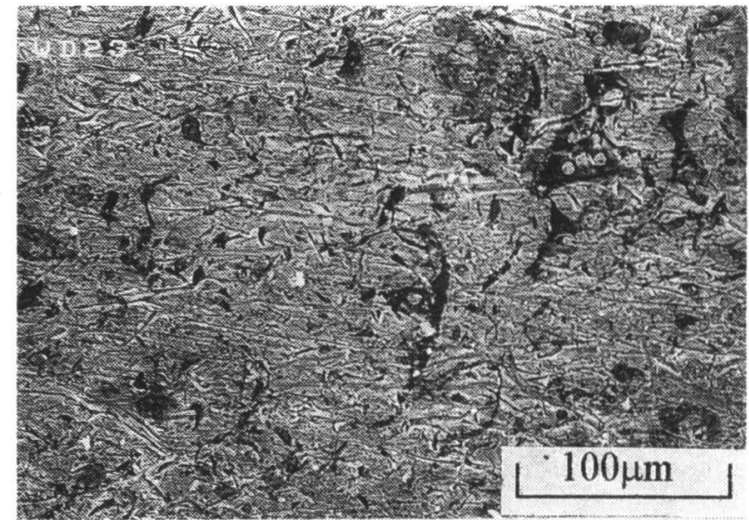

(a)

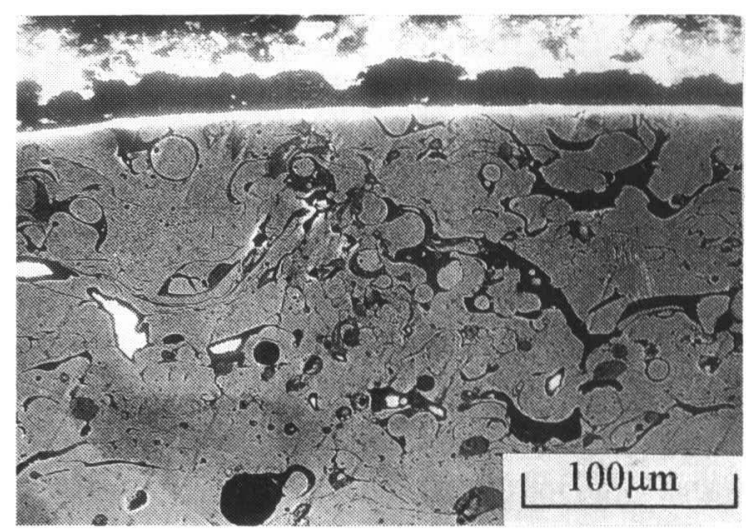

(b)

Fig. 10 Typical surface morphology and cross-sectional structure of plasma-sprayed $\mathrm{Ni}-50 \mathrm{Cr}$ coating (experimental run No. 15) after abrasive test: (a) Surface morphology ; (b) Cross-sectional structure.

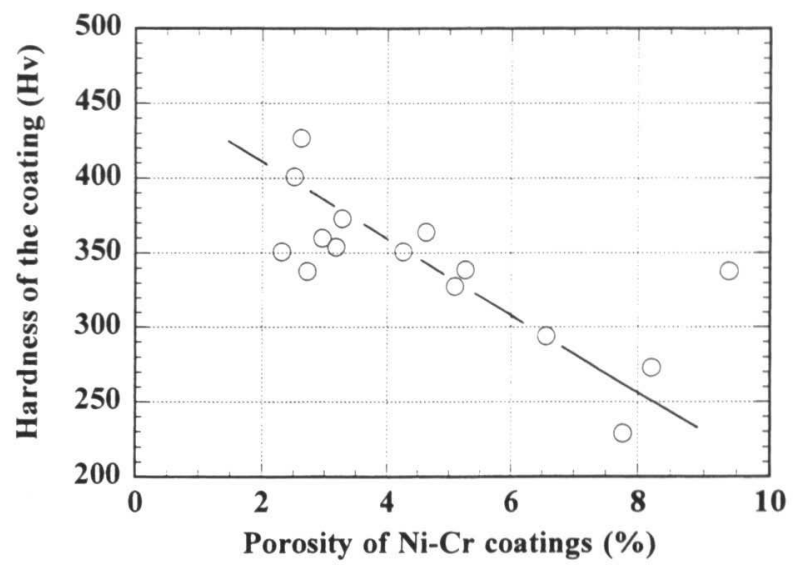

Fig. 11 Effect of porosity on the micro-hardness of plasma-sprayed $\mathrm{Ni}-50 \mathrm{Cr}$ coatings.

ミナ系セラミック溶射皮膜に対して検討した結果，エロー ジョン摩耗は主に粒子間からの粒子剝離により進行するの が明らかである ${ }^{10)}$.この場合, エロージョン摩耗速度は皮膜 粒子間の結合状態に反比例するのが示されている.

プラズマ溶射 $\mathrm{Ni}-50 \mathrm{Cr}$ 皮膜の場合では, $30^{\circ}$ と $90^{\circ}$ におけ 


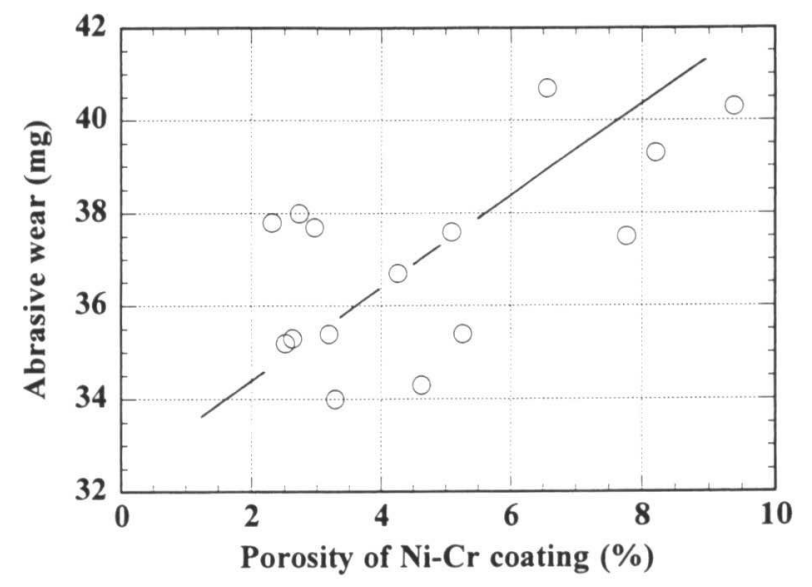

Fig. 12 Effect of porosity on the abrasive wear of plasmasprayed $\mathrm{Ni}-50 \mathrm{Cr}$ coatings.

る摩耗速度の関係から, 両者の間に良い相関性が存在し, $30^{\circ}$ での摩耗速度は $90^{\circ}$ での摩耗速度と同様な傾向を示す. これはエロージョンを支配する摩耗機構が噴射角度に大き く影響されず，同様であることを示唆するものと考えられ る. 一方, エロージョン摩耗速度は本研究の $\mathrm{Ni}-50 \mathrm{Cr}$ 皮膜 に対して, その硬さおよびアブレシブ摩耗性との間に明確 な相関性が認められなかった。これは皮膜のエロージョン 摩耗とアブレシブ摩耗が異なった機構で生じるためである

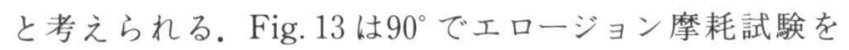
行った皮膜の断面形態の典型的な観察結果を示す. エロー ジョン摩耗後の皮膜の表面近くに存在する扁平粒子がその 下にある皮膜粒子との界面から剝離しかけているのが分か る. その摩耗断面形態から皮膜のエロージョン摩耗が粒子 間からの粒子の剝離により進行したことが明らかである. このような皮膜の摩耗機構から, プラズマ溶射 $\mathrm{Ni}-\mathrm{Cr}$ 皮膜 のエロージョン摩耗速度は皮膜の積層構造, 特に, 皮膜粒 子間の結合状態に大きく影響されると考えられる.

Fig. 8 に示したアーク電流 (出力) のエロージョン摩耗速 度への影響から, 溶射距離がある程度大きい場合, アーク 電流の増加と共に, 皮膜の摩耗速度が減少する.これは電 流によるプラズマ出力の増加に従って, 粒子の溶融状態が 改善され, 更に, 粒子速度も大きくなり, 積層される皮膜 粒子間の結合状態が改善されるためと考えられる。一方, 出力の増加と共に, 粒子に対する加熱効果が増加するが, 粒子の速度も増加するため, 粒子に対する加熱時間が短縮 されるため, 粒子の溶融状態を良くするために, 若干長い 飛行距離が必要となる。すなわち, 適切な溶射距離はプラ ズマ出力の増加に従って長くなることになる.この結果, 距離が短い場合では, 粒子溶融状態がプラズマ出力の増加 に従って逆に悪化し, 皮膜の粒子間結合状態の低下に結び つき, 皮膜のエロージョン摩耗速度の増加をもたらしたと 考えられる. 本研究の結果に基づいて最適溶射距離を 164 $\mathrm{mm}$ と求められる。例えば, 表 3 に示した 1 組から 8 組の

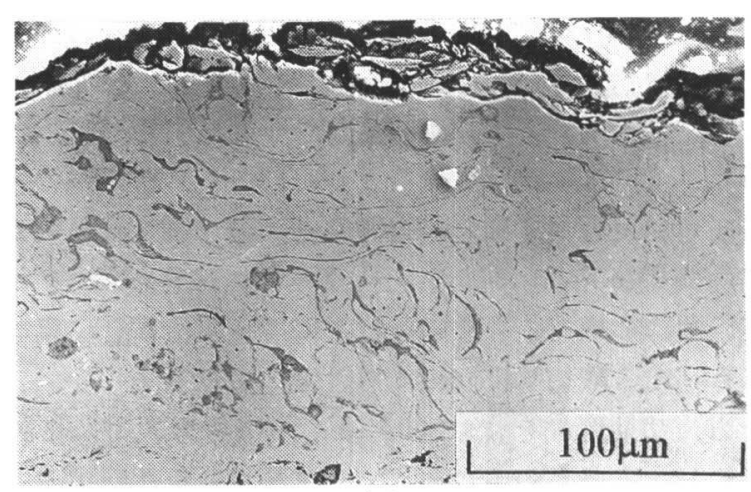

(a)

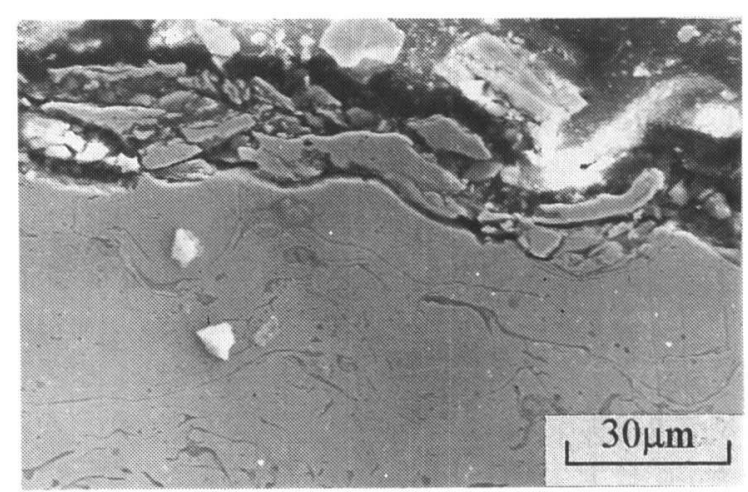

(b)

Fig. 13 Typical cross-sectional morphology of plasmasprayed $\mathrm{Ni}-50 \mathrm{Cr}$ coating (experimental run No. 1) after erosive test.

実験結果から, Ar 流量とアーク電流が同じ場合では, 120 $\mathrm{mm}$ の距離で作製した皮膜のエロージョン摩耗速度は160 $\mathrm{mm}$ に比べて大きくなっていた。

また, Fig. 1 に示したように, Ar 流量の増加と共に, 皮 膜中に未溶融粒子も認められるが, 皮膜組織は $\mathrm{Ar}$ 流量が 小さい場合に比べて, 緻密となり, 特に皮膜中の粒子間に 優先的に積層される酸化物の量が少なくなっているのが認 められた，金属皮膜中に酸化物が積層されると，皮膜粒子 間における金属組成の直接な密着の妨げになり，粒子間の 結合の悪化に結びついてしまう。その結果, Ar 流量の増加 に従って, 皮膜のエロージョン摩耗速度が減少する. 従っ て, $\mathrm{Ni}-\mathrm{Cr}$ 上うな金属溶射皮膜の場合では，その工ロ一 ジョン摩耗は粒子間にある酸化物にも大きく影響されると 考えられる.

一方, $\mathrm{Ar}$ 流量が小さい場合では, プラズマ中の水素流量 が高いため, 粒子の溶融状態, そして, 皮膜粒子間結合状 態は, $\mathrm{Ar}$ 流量に大きく影響されず, 流量の変化は皮膜の工 ロージョン摩耗速度に大きく影響を及ぼさないと考えられ る.

なお, エロージョン摩耗に対する $\mathrm{Ar}$ 流量の影響の傾向 がアブレシブ摩耗に対するそれと逆になっていた.これは， アブレシブ摩耗は主に皮膜の硬さと緻密さに依存している 
が，エロージョン摩耗は皮膜粒子間の状態，すなわち，粒 子間の結合状態及びその間にある酸化物の量と分布に大き く影響されるためと考えられる．粒子間にある酸化物は皮 膜の硬さの向上に寄与することが可能であるが，その存在 は必ず金属皮膜粒子間の結合の低下に結びつく。このため に，この様なアブレシブ摩耗特性とエロージョン摩耗特性 の皮膜組織の構造依存性の差は主に摩耗の機構と皮膜粒子 間に存在する酸化物に起因すると考之られる。

一方，初期摩耗を含む $200 \mathrm{~g}$ までの噴射摩耗材に上る各 条件における皮膜のエロージョン摩耗減量を比較すると, 粒子の溶融状態が良くなくて，皮膜中に多くの未溶融粒子 が積層された 6 組と 11 組のエロージョン摩耗減量が最も多 くなっている.この現象は噴射角度が $90^{\circ} の$ 場合に比べて, 低角度の $30^{\circ}$ の場合は顕著である．粒子の溶融状態が不完 全な場合では，積層された皮膜表面の粗さが大きくなる。 エロージョン摩耗した皮膜表面の粗さはエロージョンに よって幾らか低下するが，皮膜粒子間からの剝離により摩 耗が進行するため，摩耗後の表面に未溶融粒子が新たに現 れることになる．低角度の場合，噴射粒子が皮膜中の突起 した未溶融粒子に衝突した時に，大きな剪断力がその突起 した未溶融粒子と皮膜の界面に作用することになる。一方， 良く屚平した粒子に低角度で噴射粒子が衝突すると, 主に 摩擦力相当の力が剪断力として粒子界面に働く.その結果, 完全溶融による扁平粒子に比べて，未溶融粒子が多く存在 する皮膜のエロージョン摩耗量は大きくなると考えられ る.

一方, $90^{\circ}$ のような高角度の場合では, 主に噴射粒子の衝 撃力が作用するため, 皮膜のエロージョンは前述の上うに 主に粒子間の結合状態に支配される。従って，この結果は 皮膜中での未溶融粒子の積層は特に低角度のエロージョン 摩耗特性の低下を促進することを示すと考えられる。

\section{4. 結 論}

本研究では，直交実験計画法に基づき，プラズマアーク 出力, $\mathrm{Ar}$ 流量と溶射距離をパラメータとし, 皮膜の組織と 機械的特性に及ぼす影響を検討した。皮膜の硬さ，アブレ シブ摩耗量およびエロージョン摩耗速度はそれぞれ三つの パラメータとの定量的回帰式が求められた。本研究の結果 をまとめると，以下の通りである。

(1) Ar 水素プラズマでは，プラズマアーク電流，Ar 流量と 溶射距離は溶射粒子の溶融状態，そして，皮膜の組織に 対して，相互影響を示すフプラ゙マ出力が一定の場合， Ar 流量の増加にと共に, 皮膜中に積層される未溶融粒子 が多くなるが，皮膜中の酸化物量が少なくなり，皮膜緻 密さが増加する。

(2)溶射 $\mathrm{Ni}-\mathrm{Cr}$ 皮膜の緻密さに及ぼすプラズマアーク電流 (出力)の影響は溶射距離に大き〈依存し, 溶射距離が短 い程，その影響が顕著になるフプラズマ出力を増加し溶
射距離もある程度增加させると, 溶射粒子が完全溶融し， 皮膜が緻密になる。

(3)皮膜のアブレシブ摩耗は，その緻密さと硬さに大きく依 存する.アブレシブ摩耗に対し, 溶射パラメータは相互 影響を示し，アーク電流（出力）の影響が溶射距離に大 きく左右されるのが明らかになった。

(4)プラズマ溶射 $\mathrm{Ni}-\mathrm{Cr}$ 皮膜のエロージョン摩耗は皮膜粒 子間から生じているのが認められた。 その耐エロージョ ン摩耗性は皮膜粒子間の状態に大きく影響される。工 ロージョン摩耗に対するプラズマ電流の影響は溶射距離 に大きく依存することが明らかになった，皮膜の中での 未溶融粒子の積層は噴射摩耗角度が低くなると，エロ一ジョン摩耗を促進する効果が顕著になる，また，皮膜の エロージョン摩耗と硬さとの間には相関が認められな かった。

\section{参 考 文 献}

1) S.K. Skivastava, K.M. Godiwalla and M.K. Banerjee: Fue ash corrosion of boiler and superheater tubes, J. Mater. Sci. 32 (1997) 835.

2）原田良夫：発電用ボイラーに対方る溶射皮膜の適用例と課題, 高温学会誌, 22, Supplement (1996), p. 223.

3) S. Tobe: A review on protection from corrosion, oxidation, and hot corrosion by thermal spray coatings, Proceedings of $15^{\text {th }}$ International Thermal Spray Conference, Ed. C. Coddet, ASM International, 1998, p. 3.

4) K. Tani, Y. Harada and Y. Kobayashi : Unusual application of plasma sprayed coating for boiler tubes in oil fired boiler, Proceedings of $15^{\text {th }}$ International Thermal Spray Conference, Ed. C. Coddet, ASM International, 1998, p. 951.

5）石田 毅, 川野正和, 平木邦宏： $50 \mathrm{Ni} 20 \mathrm{Cr}$ 溶射部材の熱処理に よる熱衝撃特性の改善，溶射，Vol. 28 (No. 3)，（1991） 44.

6）村上健児，宇野直毅，岡本 平，松本宏司：Al-Si 合金およU゙ $\mathrm{Ni}$ - Cr 溶射皮膜の組織と機械的性質に及ぼす溶射中の皮膜温度の 影響, 溶射, Vol. 29 (No. 3), (1992) 22.

7) ASTM C63-69, American Society for Testing and Materials.

8）宮島生欣, 野村記生, 原田良夫, 中平 宏：化学緻密化法による 酸化物溶射皮膜の改善, 高温学会誌, Vol. 18, Supplement (1992) 307.

9) C. Takahashi and T. Senda: Microstructure measurement of plasma-sprayed alumina coating, Proceedings of $14^{\text {th }}$ International Thermal Spray Conference, Ed. A. Ohmori, Japan High Temperature Society, 1995, p. 921.

10）園家啓嗣，棍谷一郎：プラズマ溶射 $50 \mathrm{Ni}-50 \mathrm{Cr}$ 皮膜の組織構造 に及ぼす溶射条件の影響，石川島播磨技報，39，5（1999） 271.

11) C.J. Li, A. Ohmori and Y. Harada: Effect of WC particle size on the formation of HVOF sprayed WC-Co coatings, Proceedings of $14^{\text {th }}$ International Thermal Spray Conference, Ed. A. Ohmori, Japan High Temperature Society, 1995, p. 869.

12) Y. Arata, A. Ohmori and C.J. Li, Basic study on properties of plasma sprayed ceramic coatings, Trans. JWRI, Vol. 15 (1986) 339.

13）園家啓嗣, 李 長久, 紀 崗昌, 王 预躍：高速ガスフレーム溶 射法による $\mathrm{Cr}_{3} \mathrm{C}_{2}-\mathrm{NiCr}$ 皮膜の物性に及ばす溶射条件の影響, 溶接学会誌，16, 1 (1998), p. 25 . 